Document downloaded from:

http://hdl.handle.net/10251/157518

This paper must be cited as:

Romero, D.; De Jose, A.; Theureau De La Peña, JM.; Ferrer Gisbert, A.; Raigón Jiménez, MD.; Torregrosa Soler, JB. (2020). Lead in terrestrial game birds from Spain. Environmental Science and Pollution Research. 27(2):1585-1597. https://doi.org/10.1007/s11356-01906827-y

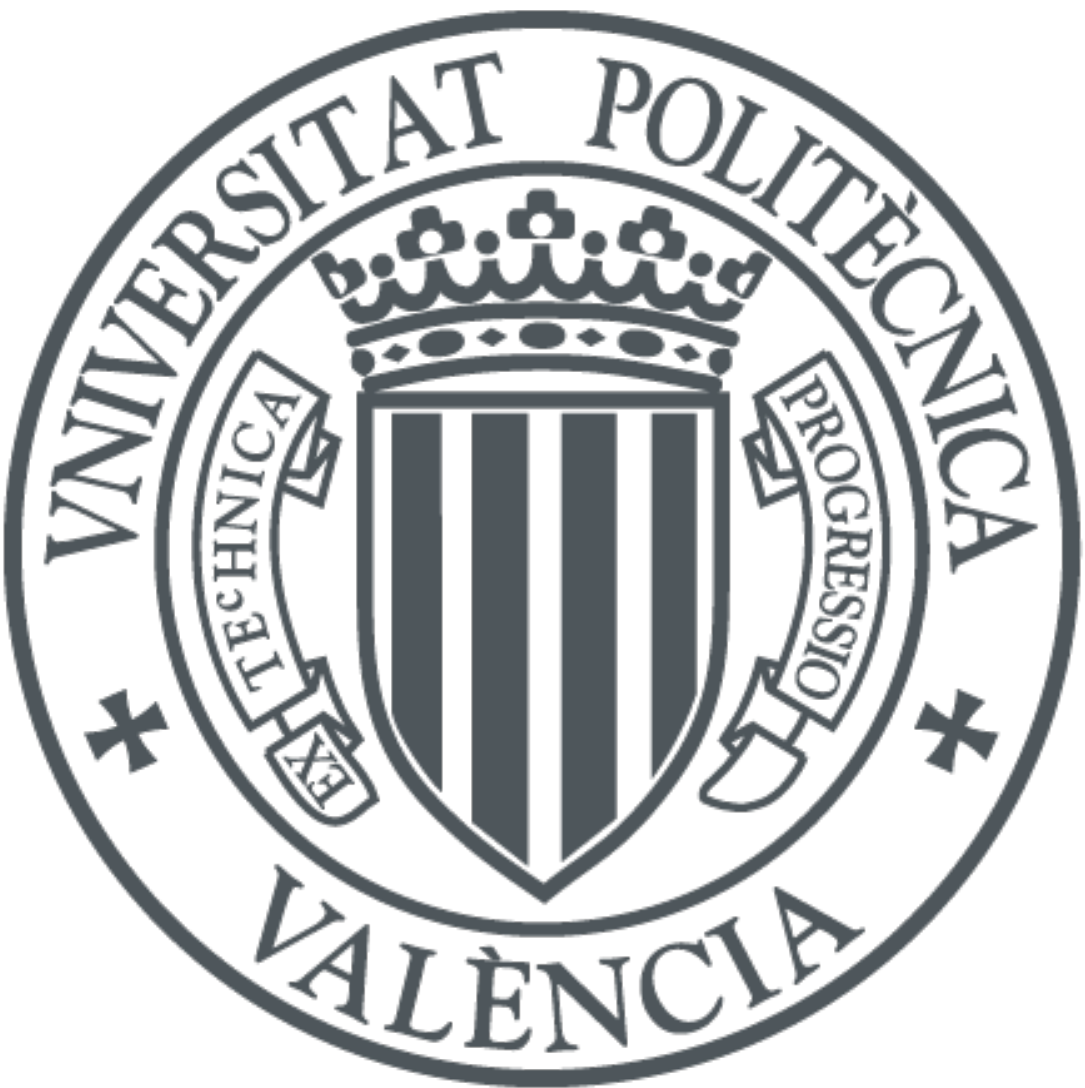

The final publication is available at

https://doi.org/10.1007/s11356-019-06827-y

Copyright Springer-Verlag

Additional Information 


\section{Lead in terrestrial game birds from Spain}

Diego Romero ${ }^{1 *}$, Antonio de José ${ }^{2}$, Juan M. Theureau ${ }^{3}$, Andrés Ferrer ${ }^{3}$, María D. Raigón ${ }^{4}$, Juan

B. Torregrosa ${ }^{3}$

${ }^{1}$ Área de Toxicología. Facultad de Veterinaria. Universidad de Murcia. Campus Regional de Excelencia Internacional “Campus Mare Nostrum”. Espinardo, E-30071, Murcia.

${ }^{2}$ Alectoris, Ingeniería y Gestión. La Iglesia, 4. Palacios del Pan, 49162, Zamora.

${ }^{3}$ Departamento de Ingeniería Rural y Agroalimentaria. Escuela Técnica Superior de Ingeniería Agronómica y del Medio Natural. Universitat Politècnica de València. Camino de Vera s/n, 46022, Valencia.

${ }^{4}$ Departamento de Química. Escuela Técnica Superior de Ingeniería Agronómica y del Medio Natural. Universitat Politècnica de València. Camino de Vera s/n, 46022, Valencia.

*Corresponding author: Diego Romero, Área de Toxicología, Facultad de Veterinaria. Campus Regional de Excelencia Internacional "Campus Mare Nostrum". Universidad de Murcia, E30071, Murcia, Spain. Tel.: +34 868 884318. diegorom@um.es 


\section{ABSTRACT}

We analysed exposure to $\mathrm{Pb}$ and its relationship with lead-based ammunition in seven species of terrestrial game birds - Common Woodpigeon (Columba palumbus), Rock Dove (Columba livia), Stock Dove (Columba oenas), European Turtle-dove (Streptopelia turtur), Red-Legged Partridge (Alectoris rufa), Barbary Partridge (Alectoris barbara) and Common Quail (Coturnix coturnix) - from rural and urban areas in different parts of Spain (Valencia, Castilla-La Mancha, Castilla y León, Madrid, Islas Canarias and Navarra). A total of 530 liver samples were analysed and the presence of $\mathrm{Pb}$ pellets was studied in the crop, gizzard and intestine; the state and appearance of these organs was also analyzed. The number of specimens suspected to have ingested $\mathrm{Pb}$ shot was 28 (5.6\%) and the geometric mean concentration of hepatic $\mathrm{Pb}$ was 0.054 $\mu \mathrm{g} \mathrm{g}^{-1}$ (wet weight, ww). A low percentage of samples (4.8\%) were above the abnormal exposure threshold $\left(0.65 \mu \mathrm{g} \mathrm{g}^{-1} \mathrm{ww}\right)$ and in these specimens renal $\mathrm{Pb}$ concentrations were determined. Common Woodpigeons and Rock Doves from Madrid were found to have high concentrations of $\mathrm{Pb}$ in their livers, and so both species can be considered to be good bioindicators of $\mathrm{Pb}$ contamination in rural (Common Woodpigeons) and urban (Rock Doves) environments. Partridges bred for hunting may be more prone to ingesting pellets from the environment, a fact that should be taken into account in management decisions.

KEY WORDS: ammunition, game birds, lead, liver, Spain, terrestrial habitats 


\section{INTRODUCTION}

Lead $(\mathrm{Pb})$ is regarded as a priority pollutant by the Agency for Toxic Substances and Disease Registry (ATSDR 2014) and the US Environmental Protection Agency (US EPA 2014). This heavy metal is common in contaminated ecosystems (Steinnes 2013) and has been extensively used by humans for centuries (Franson and Pain 2011) in a non-renewable way (Harrison 2012). In ecosystems, $\mathrm{Pb}$ is ubiquitous at all levels and is incorporated into the food chain through the atmosphere, soil, water, plants and animal tissues. However, the main source of $\mathrm{Pb}$ contamination is anthropogenic (Shotyk and Le Roux 2005) and its use as an anti-knocking agent in gasoline has contributed to its accumulation in the environment (US EPA 2003); nevertheless, currently, the major source of $\mathrm{Pb}$ in many areas of the world is secondary $\mathrm{Pb}$ produced by recycling processes (Ellis and Mirza 2010; Zhan et al. 2016), generally from discarded $\mathrm{Pb}$ acid batteries.

In recent decades, numerous studies have been conducted on the presence of $\mathrm{Pb}$ in the environment, many of which have looked at its effects on human and animal health (see review in Assi et al. 2016; and Tokar et al. 2013) and on wild birds (see review in Williams et al. 2017), as well as its presence in food (see review in EFSA 2010) and as a hazard to human health caused by Pb shot in game meat (Pain et al. 2010; Mateo et al. 2011). However, interest in wild birds' exposure to $\mathrm{Pb}$ due to the ingestion of pellets has increased in recent years and today is thought to be the most significant and widespread non-regulated source of $\mathrm{Pb}$ affecting wild animals (Pain et al. 2015), as well as one of the most frequent causes of clinical lead poisoning and death in birds (De Francisco et al. 2003; Fisher et al. 2006; Johnson et al. 2013; Pain et al. 2015).

$\mathrm{Pb}$ pellets are dispersed over the ground in hunting areas and may accumulate in certain places such as wetland sediments, where densities can be extremely high (up to 399 pellets $/ \mathrm{m}^{2}$, Mateo et al. 2007). Nevertheless, very few studies have ever been conducted on $\mathrm{Pb}$ pellet densities in terrestrial habitats and the few that have suggest densities range from 0.46 
pellets $/ \mathrm{m}^{2}$ (Hungary, Ákoshegyi 1997) to 7.4 pellets $/ \mathrm{m}^{2}$ (Spain, Ferrandis et al. 2008). These pellets may be ingested by granivorous birds (aquatic and terrestrial) as they are mistaken for grit particles, since these birds need hard structures to grind down their food (Mateo et al. 2007; Pain et al. 2009). Birds may eliminate $\mathrm{Pb}$ pellets from their digestive tracts rapidly with little absorption, or they may be retained until they are eroded away, solubilised and absorbed, or may be processed in any intermediate stage (Pain et al. 2019). Rates of $\mathrm{Pb}$ digestive absorption and particle transit times depend on the species (Holladay et al. 2012). The digestive retention time has been reported to be between two weeks and one month, approximately, in Japanese Quail (Coturnix japonica), Northern Bobwhite Quail (Colinus virginianus) and Domestic Pigeon (Yamamoto et al. 1993; Kerr et al. 2010; Holladay et al. 2012). The Pb passes into the bloodstream and into soft tissues such as the liver and kidney, although a part may be excreted. Finally, it reaches the bones, where it is deposited and remains for many years (Patrick 2006; Pokras and Kneeland 2009).

In live animals (blood) and corpses (tissues), concentrations of $\mathrm{Pb}$ serve as an indicator of exposure to this heavy metal. According to Franson and Pain (2011), the basal hepatic concentration of $\mathrm{Pb}$ in birds (Anseriformes, Falconiformes and Columbiformes) is less than 2 $m g \mathrm{~kg}^{-1}(\mathrm{ww})$, whereas clinical exposure is considered to have taken place at above $6 \mathrm{mg} \mathrm{kg}^{-1}$ (ww). Clinical signs of $\mathrm{Pb}$ poisoning in birds have been described by several authors (e.g. De Francisco et al. 2003; Patte and Pain 2003; Franson and Pain 2011), and include abnormal behaviour, anaemia, emaciation, green diarrhoea, lethargy, leg paralysis, wing droop, paralysis of the digestive tract, and convulsions. Sick birds become easy targets for predators (De Francisco et al. 2003), although some birds die rapidly without any apparent signs of having been poisoned (Pain et al. 2019). The poisoning affects a wide range of physiological and biochemical systems including the immune, haematopoietic, nervous, renal, reproductive and vascular systems (Pain et al. 2019), with severe consequences at individual and population level. 
The prevalence of $\mathrm{Pb}$ pellet ingestion and concentrations $\mathrm{Pb}$ in tissues in water birds has been the subject of numerous studies in Europe (see review in Descalzo and Mateo 2018). Indeed, the use of lead-based pellets in wetlands to hunt water birds is today restricted in several European countries. The European Chemicals Agency (ECHA) recommends the adoption of measures designed to regulate the used of lead-based ammunition in terrestrial environments (ECHA 2018). Nonetheless, only a few studies on terrestrial granivorous birds have ever been conducted in Europe, some of which are out-of-date: Denmark (Clausen and Wolstrup 1979), Spain (Soler-Rodríguez et al. 2004; Ferrandis et al. 2008), the United Kingdom (Calvert 1876; Holland 1882; Keymer 1958; Anger 1971; Keymer and Stebbings 1987; Butler et al. 2005; Potts 2005) and Hungary (Ákoshegyi 1997). The presence of birds with pellets or high Pb concentrations in their tissues constitutes a danger for any hunters who consume this kind of game (Johansen et al. 2006; Tranel and Kimmel 2009; Johnson et al. 2013). Pb concentrations can also affect predators such as birds of prey, which can be poisoned via this type of exposure (Mateo et al. 2014) leading to clinical signs such as coordination problems, no appetite, lethargy and general weakness (Carpenter et al. 2003; Patee et al. 2006).

Data describing $\mathrm{Pb}$ exposure in game birds in Spain is limited. The aim of this study was to evaluate this exposure in several species of game birds from different areas of Spain using analyses of liver $\mathrm{Pb}$ concentrations and the presence of shot in digestive tracts. This information will be useful for monitoring the presence and the availability of this heavy metal in hunting areas and as an aid when taking decisions regarding the use of $\mathrm{Pb}$ shot in terrestrial ecosystems.

\section{MATERIALS AND METHODS}

\subsection{Sample collection}


A total of 530 birds belonging to seven game-bird species were studied: Common Woodpigeon ( $n=107$, Columba palumbus), Rock Dove ( $n=99$, Columba livia), Stock Dove ( $n=30$, Columba oenas), European Turtle-dove ( $n=31$, Streptopelia turtur), Red-legged Partridge $(n=219$, Alectoris rufa), Barbary Partridge ( $n=13$, Alectoris barbara) and Common Quail $(n=31$, Coturnix coturnix). The samples were collected in 2016, 2017 and 2018 from six Spanish regions (Fig. 1) and were obtained in two ways: by hunting or by capture as part of bird control programs at airports and seaports. Data regarding sampling areas, bird characteristics and causes of death are given in Table 1. The ammunition used in firearms and compressed air guns was $\mathrm{Pb}$, while captures were made using falcons and net traps. A control group with no contact with $\mathrm{Pb}$ pellets was set up consisting of birds ( $A$. rufa) bred on a farm in Navarra. For classification of the hunting intensity - and in the absence of any official or scientific classification - we took into account the captures declared by the owners or users of the management units where hunting activities are carried out (game reserves), which we transformed into gunshots per hectare and season: very high (>30), high (10-30), moderate (5-10), low $(1-5)$, very low $(<1)$, and zero-intensity hunting. Rural, urban and periurban areas were described in terms of land uses: agricultural and forestry areas were catalogued as 'rural' and unproductive areas as 'urban'. The 'periurban' variable was only applied to a single area with agriculture and forestry in the vicinity of the built-up area around Madrid $(20 \mathrm{~km})$. The specimens hunted in Ciudad Real came from three game reserves that have been repopulated with birds from Navarra. The migratory character of species was determined according to species (S. turtur and C. coturnix) and date and place of hunting (C. palumbus).

Once birds had been hunted or euthanized, they were weighed, and their age determined by studying their feathers (primary remiges) or by other means including the presence of double spurs. Specimens were subsequently dissected to determine their sex, extract their digestive tract and take liver samples, which were transferred to microtubes and stored at $-20^{\circ} \mathrm{C}$ until analysis. Kidney samples were also taken for analysis from specimens with high hepatic $\mathrm{Pb}$ 
concentrations; in these cases we took $0.65 \mu \mathrm{g} \mathrm{g}^{-1}$ to be the more restrictive environmental exposure threshold of $\mathrm{Pb}$, according the scientific literature (Guitart et al. 1994; Ferrandis et al. 2008; Franson and Pain 2011; Berny et al. 2015; Bingham et al. 2015).

The extraction of crops was carried out with great care and they were examined for holes and pellets (Supplementary material, Fig. S1). X-rays were taken of the rest of the digestive tract to check for Pb pellets (from the junction of the proventriculus and the gizzard up to the cloaca). The gizzard and intestines were inspected for shot entry orifices and then opened up to locate any pellets detected by the X-ray and to evaluate their state (Supplementary material, Figs. S2-S5). In specimens with pellets in their digestive tracts but no entry holes, shot was considered as ingested. Finally, the colour and appearance of the gizzard mucous membrane from specimens with high hepatic $\mathrm{Pb}$ concentrations was studied.

\subsection{Metal analysis}

Tissue samples were analysed using inductively coupled plasma optical emission spectrometry (ICP-OES, ICAP 6500 Duo, Thermo Scientific, with One Fast System) to determine Pb content. Liver and kidney samples were treated with trace mineral grade nitric acid (69\% Suprapure, Merck) and 33\% H2O2 (Suprapure, Merck) in special Teflon reaction tubes, which were heated in a microwave digestion system (UltraClave-Microwave Milestone ${ }^{\circledR}$ ) for 20 min at $220^{\circ} \mathrm{C}$ and finally diluted to $10 \mathrm{ml}$ with double deionised water (MilliQ). The detection limit was $0.001 \mu \mathrm{g}$ $\mathrm{g}^{-1}$. Two replicates were analyzed for every sample; the concentration values used were the mean of the two readings. To check for possible contamination, one blank sample for every eleven samples was also analysed in the ICP-OES. Multi-element calibration standards (SCP Science, in $4 \%$ nitric acid) were prepared with specific concentrations of $\mathrm{Pb}$, taking as a reference UNE-EN ISO 11885 for the determination of elements by ICP atomic emission spectroscopy. Furthermore, intermediate patterns of all elements were prepared. The calibration device was established per batch, with a minimum of three points for every single 
lot. Each run started out with the calibration standards, continued with samples and intermediate patterns, and finished with the series with intermediate patterns (10\% variation coefficient). The wavelength was $220.353 \mathrm{~nm}$. The recovery rate for reference materials (Standard Reference Material L577b, Bovine Liver) was $98.47 \%$. Pb concentrations were expressed in micrograms per gram in wet weight $\left(\mu \mathrm{g} \mathrm{g}^{-1} \mathrm{ww}\right)$.

\subsection{Data analysis}

The data given for the metal concentrations are geometric mean, standard error, and minimum and maximum concentrations. Data below the detection limit were expressed as half of this $(0.0005)$ in order to be able to perform the statistical analysis. To check for data normality, the Shapiro-Wilk and Kolmogorov-Smirnov tests were used (according to the number of samples). A log transformation of the data was carried out on the concentration variable, and parametric mean comparison tests were conducted (ANOVA and Student's t-test; Tukey and Games Howell post-hoc test; Levene's test for equality of variances). We compared $\mathrm{Pb}$ concentrations in liver by age group and gender, by location for species ( $A$. rufa, $C$. palumbus and C. livia) and by species for location (Zamora, Madrid and Alicante), and by hunting intensity. A Chi-square test was performed to evaluate possible associations between $\mathrm{Pb}$ shot ingestion and liver $\mathrm{Pb}$ concentrations above $0.65 \mu \mathrm{g} \mathrm{g}{ }^{-1}(\mathrm{ww})$. The significance level for all tests was set at 0.05. All statistical analyses were performed with SPSS v.19.0 for Windows.

\section{RESULTS}

Specimens' weights and frequency by sex and age are given in the Supplementary material (Table S1). In all, $53.0 \%$ of birds were male and $44.5 \%$ females (the sex of the remaining $2.5 \%$ could not be determined); $49.2 \%$ were adults and $45.3 \%$ juveniles (the age of the remaining $5.5 \%$ could not be determined). 
Table 2 shows the concentrations of $\mathrm{Pb}$ detected in livers, and specimens with $\mathrm{Pb}$ shot due possibly to ingestion. The overall population's mean hepatic $\mathrm{Pb}$ concentration was $0.055 \pm 0.102$ $\mu \mathrm{g} \mathrm{g}^{-1}\left(0.054 \pm 0.107 \mu \mathrm{g} \mathrm{g}^{-1}\right.$ if we exclude the 26 farm specimens from Navarra). The percentage of samples with $\mathrm{Pb}$ concentrations above the detection limit for the entire study population was 94.3\%; the number of specimens with liver $\mathrm{Pb}$ concentrations above $0.65 \mu \mathrm{g} \mathrm{g}^{-1}$ was 24 . There were no statistically significant differences between groups in terms of either gender or age.

Hepatic $\mathrm{Pb}$ concentration in birds with shot in gizzard due to possible ingestion $(\mathrm{n}=14)$ was $0.133 \pm 0.815 \mu \mathrm{g} \mathrm{g}^{-1}$ (nd-10.379 $\mu \mathrm{g} \mathrm{g}^{-1}$ ) while in the remaining birds, the geometric mean was $0.053 \pm 0.102 \mu \mathrm{g} \mathrm{g}^{-1}$ (nd-35.567 $\mu \mathrm{g} \mathrm{g}^{-1}$ ). In birds with $\mathrm{Pb}$ shot in crop $(\mathrm{n}=6)$, the hepatic $\mathrm{Pb}$ concentration was $0.192 \pm 5.190 \mu \mathrm{g} \mathrm{g}^{-1}\left(0.005-31.253 \mu \mathrm{g} \mathrm{g}^{-1}\right)$, while it was $0.054 \pm 0.084 \mu \mathrm{g} \mathrm{g}^{-1}$ (nd-35.567 $\mu \mathrm{g} \mathrm{g}^{-1}$ ) in birds without $\mathrm{Pb}$ shot in this organ. Finally, regarding birds with $\mathrm{Pb}$ shot in intestine $(\mathrm{n}=10)$, the hepatic $\mathrm{Pb}$ concentration was $0.134 \pm 0.774 \mu \mathrm{g} \mathrm{g}^{-1}\left(0.005-7.885 \mu \mathrm{g} \mathrm{g}^{-1}\right)$, and $0.054 \pm 0.103 \mu \mathrm{g} \mathrm{g}^{-1}$ (nd-35.567 $\mu \mathrm{g} \mathrm{g}^{-1}$ ) in birds without $\mathrm{Pb}$ shot. Two specimens presented pellets located in two tissues: intestine and gizzard, and in intestine and crop. Differences between groups with and without $\mathrm{Pb}$ shot were no significant.

Hepatic $\mathrm{Pb}$ concentrations in A. rufa, C. palumbus and C. livia by location are shown in Table 3. In the case of Red-legged Partridges, the mean hepatic concentration of Pb from all locations was below $0.100 \mu \mathrm{g} \mathrm{g}^{-1}$. In this species, the highest mean concentration was detected in birds from Alicante, followed by birds from Ciudad Real and Navarra (farm partridges); there were no statistical differences between these birds, but there were differences from birds from Valencia and Zamora. The analysis of the results for Common Woodpigeons reveals a higher hepatic mean concentration of $\mathrm{Pb}(\mathrm{p}<0.05)$ in pigeons from Madrid than in birds from Zamora and Alicante; there were no differences ( $p>0.05$ ) between specimens from Zamora and Alicante. In the case of Rock Doves, the highest mean concentrations were found in doves 
from Madrid, followed by Valencia; there were no statistical differences between these birds, but there were significant differences with the Rock Doves from Zamora and Alicante.

$\mathrm{Pb}$ concentrations in liver by location are shown in Table 4. In Zamora, there were differences $(p<0.05)$ between $C$. coturnix and $C$. palumbus and the remaining species, but no differences ( $p>0.05)$ between pigeon species from Madrid. In Alicante there were only statistically significant differences between the Rock Dove and the Red-legged Partridge, and between the Rock Dove and the Common Woodpigeon.

In terms of environments, there were statistically significant differences in hepatic $\mathrm{Pb}$ concentrations between specimens from areas with different hunting intensity (Table 5). By species, there were no significant differences between specimens from areas of low and very high hunting intensity in the case of Common Woodpigeons ( $0.047 \mathrm{vs} 0.055 \mu \mathrm{g} \mathrm{g}^{-1}$ ); birds from areas with high hunting intensity (Madrid, $0.180 \mu \mathrm{g} \mathrm{g}^{-1}$ ) had greater $\mathrm{Pb}$ concentration $(\mathrm{p}<0.05)$ than specimens from low and very high hunting intensity. In Rock Doves, there were no significant differences between specimens from areas of low and very high hunting intensity $\left(0.022\right.$ vs $\left.0.020 \mu \mathrm{g} \mathrm{g}^{-1}\right)$; there were significant differences between specimens from areas with high-intensity hunting $\left(0.187 \mu \mathrm{g} \mathrm{g}^{-1}\right)$ and specimens from areas with very high $\left(0.020 \mu \mathrm{g} \mathrm{g}^{-1}\right)$ and low hunting intensity $\left(0.022 \mu \mathrm{g} \mathrm{g}^{-1}\right)$. In the case of Red-legged Partridges, there were statistically significant differences between the specimens hunted in low hunting intensity areas $\left(0.024 \mu \mathrm{g} \mathrm{g}^{-1}\right)$ as opposed to high and very high hunting intensity areas (0.065 and 0.070 $\mu \mathrm{g} \mathrm{\textrm {g } ^ { - 1 }}$, respectively). There were no statistical differences in liver $\mathrm{Pb}$ concentration between both pigeon species from Madrid, but there were differences $(p<0.05)$ between each pigeon species from Madrid and partridges from Ciudad Real.

The number of pellets found in birds' crops was 22 from a total of 20 specimens; we found shot entry orifices on the crop's surface in 16 specimens. The number of pellets found in the rest of the digestive tract were 78 inside the gizzard ( 55 specimens) and 18 inside the intestine 
(13 specimens). We found 21 pellets (19 specimens) embedded in the gizzard muscle layers and serous membrane. Of the specimens with pellets in the gizzard and/or intestinal lumen, no apparent shot entry orifices were found in 24 . The total number of specimens containing pellets inside one or more of these three organs but without an apparent shot entry-orifice totalled 28 ( $5.3 \%$ of the total population, $5.6 \%$ if we exclude the farm specimens, Table 2 ).

There was a weak association $(\mathrm{V}$ of $\mathrm{Cramer}=0.190 ; \mathrm{p}<0.05)$ between the possible ingestion of $\mathrm{Pb}$ shot and liver $\mathrm{Pb}$ concentrations above $0.65 \mu \mathrm{g} \mathrm{g}^{-1}$. By hunting intensity area, we only found this statistical association in birds from high hunting intensity areas ( $V$ of Cramer= 0.269 ); by location, this statistical association only existed for Ciudad Real (V of Cramer= 0.359$)$.

\section{DISCUSSION}

\section{1. $\mathrm{Pb}$ in livers of the studied bird groups}

In terrestrial habitats, most of the studies conducted to date have analyzed the presence of $\mathrm{Pb}$ ammunition in bird corpses and its role as the cause of death, and its impact on birds of prey that feed on them (Fisher et al. 2006; Pain et al. 2009; Berny et al. 2015; Carneiro et al. 2016; Williams et al. 2017). On the other hand, few studies have ever evaluated tissue concentrations of $\mathrm{Pb}$ in apparently healthy game bird populations (DeMent et al. 1987; SolerRodríguez et al. 2004; Ferrandis et al. 2008; Kreager et al. 2008). In our study, the hepatic mean value found for the entire population $(n=530)$ was $0.055 \mu \mathrm{g} \mathrm{g}^{-1}\left(0.054 \mu \mathrm{g} \mathrm{g}^{-1}\right.$ if we exclude the 26 farm specimens); only the groups from Madrid and two groups from Zamora (the Rock Dove from Santa Cruz de Tenerife with a value of $0.161 \mu \mathrm{g} \mathrm{g}^{-1}$ was not considered, since there was only a single specimen) exceeded the value of $0.100 \mu \mathrm{g} \mathrm{g}^{-1}$ (Table 2). For livers of $A$. rufa from Spain, Ferrandis et al. (2008) reported means of 2.17 and $0.58 \mu^{-1} \mathrm{~g}^{-1}$ (dry weight) of $\mathrm{Pb}$, higher values than those found in our study (according Franson and Pain 2011, $1 \mu^{g^{-1}}$ wet weight is equal to approximately $3.1 \mu \mathrm{g} \mathrm{g}^{-1}$ of the liver's dry weight). The data reported by 
Soler-Rodríguez et al. (2004) for the same species gives a geometric mean of $0.073 \mu \mathrm{g} \mathrm{g}^{-1} \mathrm{ww}$, a value slightly higher than that obtained in our study. If we consider the above-mentioned criteria regarding the more limited environmental exposure threshold of $\mathrm{Pb}\left(0.65 \mu \mathrm{g} \mathrm{g}^{-1} \mathrm{ww}\right)$, 95.5\% of the studied population (95.2\% if the farm partridges are excluded) had a hepatic $\mathrm{Pb}$ concentrations below that value. According Franson and Pain (2011), basal Pb concentrations in the liver are less than $2 \mu \mathrm{g} \mathrm{g}^{-1}(\mathrm{ww})$; in our study $96.8 \%$ of specimens $(96.6 \%$ if the farm partridges are excluded) had $\mathrm{Pb}$ liver concentrations below that level. Thus, most of the populations did not have abnormal $\mathrm{Pb}$ concentrations.

When the total population of birds was analyzed, we found that there were no statistically significant differences between age groups and sexes, which coincides with the findings reported by Cui et al. (2013) in homing pigeons.

\subsection{Analysis by species and locations}

In Red-legged Partridges we found no differences between specimens originating from locations with very different characteristics (Table 3): an area dedicated to breeding birds in captivity (Navarra) and rural areas of high or very high hunting intensity (Ciudad Real and Alicante). However, $\mathrm{Pb}$ concentrations in partridges from these locations were higher $(\mathrm{p}<0.05)$ than those found in Zamora. According the Geochemical Atlas of Spain (2019), Pb concentrations in soil from the sampling areas in Zamora are $20.7-32.0 \mu \mathrm{g} \mathrm{g}^{-1}$, as opposed to 69.3-69.7 $\mathrm{mg} \mathrm{g}^{-1}$ from Ciudad Real and $39.1 \mu \mathrm{g} \mathrm{g}^{-1}$ from Alicante. Also, the hunting intensity in Zamora was the lowest, which could explain these results. However, $\mathrm{Pb}$ concentrations in soil from Navarra were very low (12.9-17.9 $\left.\mathrm{g} \mathrm{g} \mathrm{g}^{-1}\right)$, which not explain the liver Pb concentrations that we found for this area. On the other hand, the mean $\mathrm{Pb}$ concentrations were very low in the five locations $\left(<0.070 \mu \mathrm{g} \mathrm{g}^{-1}\right)$ and, as we have indicated above, lower than those reported in partridges from other areas of Spain (Soler-Rodríguez et al. 2004; Ferrandis et al. 2008). 
The statistical differences observed between Alicante and Zamora for partridges were not replicated in either species of pigeons (Table 3). Several authors have reported that Rock Doves are good indicators of environmental contamination (Antonio García et al. 1988; Nam and Lee 2006; Cui et al. 2013; Cai and Calisi 2016), and they have been used in several countries to determine exposure levels to heavy metals in urban environments. However, and according our results (with no statistical differences between pigeons from Zamora and Alicante), these species do not seem to be the best indicators of exposure levels to this heavy metal in rural environments. Liver $\mathrm{Pb}$ concentrations in both Common Woodpigeon and Rock Doves from Madrid were higher $(p<0.05)$ than those found in rural environments (Zamora and Alicante), with no differences between them (Table 4). As well, in Valencia $\mathrm{Pb}$ liver concentrations in $C$. livia were higher $(p<0.05)$ than those we found in $A$. rufa (Table 4). According to Schilderman et al. (1997), hepatic concentrations of $\mathrm{Pb}$ in pigeons in control zones in the Netherlands were $0.13-0.16 \mu \mathrm{g} \mathrm{g}^{-1}(\mathrm{ww})$. Other authors give higher concentrations for pigeons in control zones, reaching $2.01 \mathrm{\mu g} \mathrm{g}^{-1}$ dry weight (Hutton and Goodman 1980, equivalent to $0.65 \mu \mathrm{g} \mathrm{g}^{-1}$ in wet weight, applying the conversion factor of 3.1 suggested by Franson and Pain 2011), and $1.57 \mu \mathrm{g} \mathrm{g}^{-1} \mathrm{ww}$ (Nam and Lee 2006). Although the $\mathrm{Pb}$ concentrations in the livers of Common Woodpigeons and Rock Doves in our study were low, we can at least affirm that there is a relationship between a periurban environment and higher concentrations of $\mathrm{Pb}$ in pigeon species. This finding is supported by the fact that no differences were observed $(\mathrm{p}>0.05)$ in liver $\mathrm{Pb}$ concentrations in Rock Doves from Madrid and Valencia (seaport) (Table 3), the latter an unproductive area with high Pb concentrations in the soil (104 $\mu \mathrm{g} \mathrm{g} \mathrm{g}^{-1}$, Geochemical Atlas of Spain 2019).

Common Quails had the highest $\mathrm{Pb}$ liver concentrations (above $0.100 \mu \mathrm{g} \mathrm{g} \mathrm{g}^{-1}$, Table 4) in Zamora. Although this is a migratory species, Common Quails live in hunting areas from spring onwards and several authors have reported that this species can be either migrants, partial migrants or sedentary (Fontoura et al. 2000; Mur 2009). According to Nadal et al. (2019), 
several parts of the Iberian Peninsula are home to sedentary Common Quail populations. As well, $61.2 \%$ of the hunted specimens in our study were juveniles (see Supplementary material, Table S1) born in the study area, so this species could be a bioindicator for monitoring in this area.

In Alicante (where hunting was most intense), four species (Common Woodpigeon, Rock Dove, European Turtle-dove and Red-legged Partridge) were hunted but there were only statistically significant differences between the Rock Dove and the Red-legged Partridge, and between the Rock Dove and the Common Woodpigeon. Differences between these two species of pigeon were found in both Zamora and Alicante. As mentioned above, the Rock Dove is an ideal bioindicator species in urban environments (Antonio García et al. 1988; Nam and Lee 2006; Cui et al. 2013; Cai and Calisi 2016) and we suggest that the Common Woodpigeon could be a better bioindicator species in rural environments than the Rock Dove.

\subsection{Differences associated with hunting intensity and shot ingestion}

Pigeons from high hunting intensity areas (Madrid) were hunted in places with $\mathrm{Pb}$ concentrations in soil of $60.6 \mu \mathrm{g} \mathrm{g}{ }^{-1}$, similar concentrations to those reported from Ciudad Real (69.3-69.7 $\mathrm{Mg} \mathrm{g}^{-1}$ ) (Geochemical Atlas of Spain 2019), which suggests that differences between both locations (Table 5) were derived from the other sources. Pigeons samples were taken in an area $20 \mathrm{~km}$ from Madrid, one of the largest metropolitan areas in Europe. Heavy metals such as $\mathrm{Pb}$ are released in different particle sizes in the urban atmosphere remaining in urban soils for a long time and act as sources of further pollution (Argyropoulos et al. 2012; PeñaFernández et al. 2015), which could have affected these results.

For Red-legged Partridges, we have found differences between areas with low $\left(0.024 \mu \mathrm{g} \mathrm{g}^{-1}\right)$ and high and very high hunting intensity $\left(0.065\right.$ and $0.070 \mu \mathrm{g} \mathrm{g}^{-1}$, with no differences between them). Additionally, we also found a statistical association between liver $\mathrm{Pb}$ concentrations 
above $0.65 \mu \mathrm{g} \mathrm{g}^{-1}$ and possible shot $\mathrm{Pb}$ ingestion, even though this association was derived from partridges from Ciudad Real (high hunting intensity). Wild birds ingest $\mathrm{Pb}$ pellets resembling weed seeds and grain or grit particles to grind down food (Conti 1993; Mirarchi and Baskett 1994; Kendall et al. 1996; Mateo et al. 2007; Pain et al. 2009). According to several authors, hunters leave high quantities of $\mathrm{Pb}$ shot in relatively small areas (Castrale 1989; Best et al. 1992; Kendall et al. 1996; Schulz et al. 2002), which accumulate during the hunting season. Thus, specimens from areas with different levels of hunting intensity should show differences in liver $\mathrm{Pb}$ concentrations. However, in the seven specimens (four pigeons and three partridges) and eight (seven pigeons and one partridge) with possible $\mathrm{Pb}$ shot ingested from areas with very high and low hunting intensity, there were no statistical associations with high liver $\mathrm{Pb}$ concentrations and so it would seem that the species was important in determining how much shot was ingested.

\subsection{Specimens with $\mathrm{Pb}$ shot in their digestive tracts and hepatic $\mathrm{Pb}$ concentrations above the threshold for environmental exposure}

We found hepatic $\mathrm{Pb}$ concentrations over $0.65 \mu \mathrm{g} \mathrm{g}^{-1}$ (the lowest value found in the bibliography as a threshold for environmental exposure) in 24 specimens ( $4.5 \%$ of the total population under study, $4.8 \%$ without taking the farm partridge population into account) (Supplementary material, Table S2). Of these specimens, only eight had $\mathrm{Pb}$ pellets in their crops, gizzards or intestines, and only six birds had no apparent shot entry orifices ( $1.2 \%$ of the population, without taking farm specimens into account). If we assume that an intake of pellets as grit only occurred in these cases, our findings are similar to or lower than those reported by other authors (Table 6). Moreover, if we analyse these results by species, we find that it includes $0.9 \%$ of Common Woodpigeons, $0 \%$ of Common Quails, Rock Doves, Stock Doves, European Turtle-doves and Barbary Partridges, and 2.6\% of Red-legged Partridges 
(without taking into account farm partridges). Thus, in our study, the percentage for the latter species is lower than the data reported previously from Spain (Table 6).

However, the rest of the specimens may have expelled the pellets. In order to analyse the results with this possibility in mind, we took the following into account: (1) renal $\mathrm{Pb}$ concentrations and (2) the colour and appearance of the gizzard mucous membrane (Supplementary material, Table S2). Furthermore, we also considered ideas put forward by other authors: (1) renal concentrations of $\mathrm{Pb}$ tend to be higher than hepatic concentrations (DeMent et al. 1987; Franson and Pain 2011); (2) the concentrations of Pb in the soft tissues of birds that have ingested metal $\mathrm{Pb}$ tend to be very biased or have atypical values (Dieter 1979; Beyer et al. 1998); (3) there are sometimes erroneous values in measurements when ammunition fragments are left embedded in the tissue (Kreager et al. 2008); (4) gizzards tend to be dark in colour when exposed to Pb (De Francisco et al. 2003; Franson and Pain 2011); and (5) concentrations of $\mathrm{Pb}$ in the liver of birds over the aforementioned threshold of $0.65 \mu \mathrm{g} \mathrm{g}^{-1}$ have been found in large cities (Hutton and Goodman 1980; Schilderman et al. 1997; Nam and Lee 2006).

Based on all the cited scientific references, there seems to be some evidence of high $\mathrm{Pb}$ concentrations resulting from a possible ingestion of $\mathrm{Pb}$ pellets in fifteen birds (Supplementary material, Table S2, specimens $3,4,6,7,9,10,11,12,13,14,15,16,17,18$ and 24 , the final one at the limit of the threshold), which corresponds to $3.0 \%$ of all the specimens studied (without taking farm specimens into account). There were also another four specimens that should be treated with caution, since the $\mathrm{Pb}$ concentration in one of their organs was very low but excessively high in the other (specimens 1, 2, 20 and 23), although the colour of their gizzards showed no evidence of $\mathrm{Pb}$ shot ingestion. If these specimens' tissue concentrations are correct and there were no embedded ammunition fragments, we should have found clinical signs of poisoning, which was not the case. However, several authors have reported a 
greater resilience to $\mathrm{Pb}$ poisoning in some bird species, including partridges and pigeons (Barthalmus et al. 1977; Bannon et al. 2011; Franson and Pain 2011). If we were to include these specimens, the percentage would rise to $3.8 \%$ (19 specimens), a percentage still below those reported from Spain (Soler-Rodríguez et al. 2004; Ferrandis et al. 2008), Hungary (Ákoshegyi 1997), Canada (Kreager et al. 2008) and USA (DeMent et al. 1987; Walter and Reese 2003; Larsen et al. 2007; Bingham et al. 2015).

In the remaining five specimens $\mathrm{Pb}$ pellet ingestion does not seem to have occurred given the normal appearance of their gizzards' internal surfaces, and given the existence of concentrations situated between the two threshold values set for hepatic $\mathrm{Pb}\left(0.65-2.0 \mu \mathrm{g} \mathrm{g}{ }^{-1}\right.$, specimens 19, 21 and 22), their renal Pb concentrations within the limits considered (specimen 19), their high hepatic concentrations but low renal concentrations (specimens 5 and 8), and origin from urban areas (specimens 19 and 22). The dark-green staining of the gizzard membrane could be associated with the ingestion of lead shot many years ago (Locke and Bagley 1967; McConnell 1968) and is considered an important diagnostic sign (De Francisco et al. 2003).

Finally, we observed that there was some evidence that at least eight of these 24 specimens had been bred and released into the wild for hunting (cage marks on feathers). Partridges are commonly released in intensive hunting estates where lead shot densities in soil could be high, which means that the study of $\mathrm{Pb}$ shot densities could be relevant to this result.

\section{Conclusion}

We can affirm that the wild bird populations analysed had low hepatic $\mathrm{Pb}$ concentrations (median of $0.054 \mu \mathrm{g} \mathrm{g}^{-1}$ ) and that the $\mathrm{Pb}$ concentrations in a large percentage (95.2\%) of the specimens were below the environmental exposure threshold. There was some evidence of the ingestion of $\mathrm{Pb}$ pellets in a small percentage of birds (3.0-3.8\%), and in some specimens, 
exposure to $\mathrm{Pb}$ seems to be due to urban sources. Birds bred for hunting seem to be more prone to ingesting pellets from the environment, probably because of the high hunting intensity in their release areas, a fact that should be taken into consideration when taking management decisions. There appears to be a relationship between the hepatic concentrations of $\mathrm{Pb}$ in pigeons and their life in urban environments. In low-intensity hunting environments, Common Quails and Common Woodpigeons should be chosen for $\mathrm{Pb}$ contamination monitoring studies. The Rock Dove has been suggested by several authors as a good indicator of contamination in urban environments, while the Common Woodpigeon could be a good indicator in rural environments.

\section{Acknowledgments}

This study was funded by the Spanish Sectoral Federation of Weapons and Ammunition (FSA). The authors would like to thank Miguel A. Sánchez Isarria for his help in collecting samples, to Valentín Urrutia and Inma Salvat for their help in processing the samples, to Alberto Ferrer (Departamento de Estadística e Investigación Operativa Aplicadas y Calidad, Universidad Politécnica de Valencia) for the statistical treatment of the data, and the Department of Animal Surgery at the Veterinary Clinical Hospital of the University of Murcia for conducting the X-ray analyses of the samples.

\section{References}

Ákoshegyi I (1997) Lead poisoning of pheasants caused by lead shots. Magy Allatorvosok Lapja 119(6):328-330.

Anger H (1971) Gamebird diseases. The Game Conservancy Trust Annual Review 2:51-53.

Antonio García MT, Martínez-Conde E, Corpas-Vázquez I (1988) Lead levels of feral pigeons (Columba livia) from Madrid (Spain). Environ Pollut 54:89-96. 
Argyropoulos G, Manoli E, Kouras A, Samara C (2012) Concentrations and source apportionment of PM10 and associated major and trace elements in the Rhodes Island, Greece. Sci Total Environ 432:12-22. doi: 10.1016/j.scitotenv.2012.05.076.

Assi MA, Hezmee MNM, Haron AW, Sabri MY, Rajion MA (2016) The detrimental effects of lead on human and animal health. Vet World 9(6):660-671.

ATSDR (2014) Agency for Toxic Substances and Disease Registry, Division of Toxicology and Environmental Medicine Atlanta, GA 30333 (April 2014), Support document to the 2013 priority list of hazardous substances that will be the subject of toxicological profiles. http://www.atsdr.cdc.gov/SPL/resources/ATSDR_2013_SPL_Support_Document.pdf.

Bannon DI, Parsons PJ, Centeno JA, Lal S, Xu H, Rosencrance AB, Dennis WE, Johnson MS (2011) Lead and copper in pigeons (Columbia livia) exposed to a small arms-range soil. Arch Environ Contam Toxicol 60:351-360.

Barthalmus GT, Leander JD, Mc-Millan DE, Mushak P, Krigman MR (1977) Chronic effects of lead on schedule-controlled pigeon behavior. Toxicol Appl Pharmacol 42:271-284.

Berny P, Vilagines L, Cugnasse JM, Mastain O, Chollet JY, Joncour G, Razin M (2015) Vigilance poison: Illegal poisoning and lead intoxication are the main factors affecting avian scavenger survival in the Pyrenees (France). Ecotoxicol Environ Saf 118:71-82.

Best TL, Garrison TE, Schmitt CG (1992) Availability and ingestion of lead shot by mourning doves (Zenaida macroura) in southeastern New Mexico. Southwest Nat 37:287-292.

Beyer WN, Franson JC, Locke LN, Stroud RK, Sileo L (1998) Retrospective study of the diagnostic criteria in a lead-poisoning survey of waterfowl. Arch Environ Contam Toxicol 35:506-512. 
Bingham RJ, Larsen RT, Bissonette JA, Hall JO (2015) Widespread ingestion of lead pellets by wild chukars in northwestern Utah. Wildl Soc Bull 39(1):94-102.

Butler DA (2005) Incidence of lead shot ingestion in red-legged partridges (Alectoris rufa) in Great Britain. Vet Rec 157:661-662.

Butler DA, Sage RB, Draycott RAH, Carroll JP, Potts D (2005) Lead exposure in ring-necked pheasants on shooting estates in Great Britain. Wildl Soc Bull 33:583-589.

Cai F, Calisi RM (2016) Seasons and neighborhoods of high lead toxicity in New York City: The feral pigeon as a bioindicator. Chemosphere 161:274-279.

Calvert HS (1876) Pheasants poisoned by swallowing shot. The Field 47:189.

Carneiro MA, Oliveira PA, Brandão R, Francisco ON, Velarde R, Lavín S, Colaço B (2016) Lead Poisoning Due to Lead-Pellet Ingestion in Griffon Vultures (Gyps fulvus) From the Iberian Peninsula. J Avian Med Surg 30(3):274-279.

Carpenter JW, Pattee OH, Fritts SH, Rattner BA, Wiemeyer SN, Royle JA, Smith MR (2003) Experimental lead poisoning in turkey vultures (Cathartes aura). J Wildl Dis 39(1):96-104.

Castrale JS (1989) Availability of spent lead shot in fields managed for mourning dove hunting. Wild Soc Bull 17:184-189.

Clausen B, Wolstrup C (1979) Lead poisoning in game from Denmark. Dan Rev Game Biol 11:122.

Conti JA (1993) Diseases, parasites, and contaminants. In: Baskett TS, Sayer MW, Tomlinson RE and Mirarchi RE (eds) Ecology and management of the mourning dove. Wildlife Management Institute, Washington, D.C., USA, p:205-224. 
Cui J, Wu B, Hallbrook RS, Zang S (2013) Age-dependent accumulation of heavy metals in liver, kidney and lung tissues of homing pigeons in Beijing, China. Ecotoxicology 22:1490-1497.

De Francisco N, Ruiz Troya JD, Agüera El (2003) Lead and lead toxicity in domestic and free living birds. Avian Pathol 32(1):3-13.

DeMent SH, Julian Chisolm Jr J, Eckhaus MA, Strandberg JD (1987) Toxic lead exposure in the urban rock dove. J Wildl Dis 23(2):273-278.

Descalzo E, Mateo R (2018) La contaminación por munición de plomo en Europa: el plumbismo aviar y las implicaciones en la seguridad de la carne de caza. Instituto de Investigación en Recursos Cinegéticos (IREC), Ciudad Real, Spain. 82 pp.

Dieter MP (1979) Blood delta-aminolevulinic acid dehydratase (ALAD) to monitor lead contamination in canvasback ducks (Aythya valisineria). In: Nielsen SWG, Migaki G, Scarpelli DG (eds) Animals as monitors of environmental pollutants. Washington, D.C., National Academy of Sciences:177-191.

ECHA (2018) Annex XV Investigation Report. A review of the available information on lead in shot used in terrestrial environments, in ammunition and in fishing tackle. European Chemicals Agency. In: https://echa.europa.eu/-/echa-identifies-risks-to-terrestrialenvironment-from-lead-ammunition.

EFSA (2010) Panel on Contaminants in the Food Chain (CONTAM). Scientific Opinion on Lead in Food. EFSA Journal 8(4), 1570, 151 pp.

Ellis TW, Mirza AH (2010) The refining of secondary lead for use in advanced lead- acid batteries. J Power Sources 195(14):4525-4529. 
Ferrandis P, Mateo R, López-Serrano FR, Martínez-Haro M, Martínez-Duro E (2008) Lead-shot exposure in Red-legged Partridge (Alectoris rufa) on a driven shooting estate. Environ Sci Technol 42:6271-6277.

Fisher IJ, Pain DJ, Thomas VG (2006) A review of lead poisoning from ammunition sources in terrestrial birds. Biol Conserv 131:421-432.

Fontoura A, Gonçalves D, Guyomarc'h JC, Saint-Jalme M (2000) La sexualité précoce des populations hivernantes de Cailles des blés. Cah d'Ethologie 20:21-34.

Franson JC, Pain DJ (2011) Lead in birds. In: Nelson W Beyer \& Meadorv JP (eds) Environmental Contaminants in Biota: Interpreting Tissue Concentrations, 2nd edition, Boca Raton, CRC:563-593.

Geochemical Atlas of Spain (2019) Geological and Mining Institute of Spain, Government of Spain's Ministry of Science, Innovation and Universities. http://info.igme.es/geoquimica/ (access May 15, 2019).

Guitart R, To-Figueras J, Mateo R, Bertolero A, Cerradelo S, Martínez-Vilalta A (1994) Lead poisoning in waterfowl from the Ebro Delta, Spain: Calculation of lead exposure thresholds for mallards. Arch Environ Contam Toxicol 27:289-293.

Harrison R (2012) Lead Pollution: Causes and Control. Springer Science \& Business Media. Berlin, Germany.

Holladay JP, Nisanian M, Williams S, Tuckfield RC, Kerr R, Jarrett T, Tannenbaum L, Holladay SD, Sharma A, Gogal RM Jr (2012) Dosing of adult pigeons with as little as one \#9 lead pellet caused severe $\delta$-ALAD depression, suggesting potential adverse effects in wild populations. Ecotoxicology 21(8):2331-2337. doi: 10.1007/s10646-012-0989-x. 
Holland G (1882) Pheasant poisoned by swallowing shot. The Field 59:232.

Hutton M, Goodman GT (1980) Metal contamination of feral pigeons Columba livia from the London area. Part I: tissue accumulation of lead cadmium and zinc. Environ Pollut Ser A 22:207-217.

Johansen P, Pedersen HS, Asmund G, Riget F (2006) Lead shot from hunting as a source of lead in human blood. Environ Pollut 142(1):93-97.

Johnson CK, Kelly TR, Rideout BA (2013) Lead in ammunition: a persistent threat to health and conservation. Ecohealth 10(4):455-464.

Kendall RJ, Lacher Jr TE, Bunck C, Daniel B, Driver C, Grue CE, Leighton F, Stansley W, Watanbe, PG, Whitworth M (1996) An ecological risk assessment of lead shot exposure in nonwaterfowl avian species: upland game birds and raptors. Environ Toxicol Chem 15:4-20.

Kerr R, Holladay S, Jarrett T, Selcer B, Meldrum B, Williams S, Tannenbaum L, Holladay J, Williams J, Gogal R (2010) Lead pellet retention time and associated toxicity in northern bobwhite quail (Colinus virginianus). Environ Toxicol Chem 29(12):2869-74. doi: 10.1002/etc.355.

Keymer IF (1958) A survey and review of the causes of mortality in British birds and the significance of wild birds as disseminators of disease. Vet Rec 70:713-720.

Keymer IF, Stebbings RSJ (1987) Lead poisoning in a Partridge (Perdix perdix) after ingestion of gunshot. Vet Rec 120:276-277.

Kreager N, Wainman BC, Jayasinghe RK, Tsuji LS (2008) Lead pellet ingestion and liver-lead concentrations in upland game birds from Southern Ontario, Canada. Arch Environ Contam Toxicol 54:331-336. 
Larsen RT, Flinders JT, Mitchell DL, Perkins ER (2007) Grit size preferences and confirmation of ingested lead pellets in Chukars (Alectoris chukar). West N Am Nat 67(1):152-155.

Locke LN, Bagley GE (1967) Lead poisoning in a sample of Maryland mourning doves. J Wildl Mgmt 31:515-518.

Mateo R, Baos AR, Vidal D, Camarero PR, Martinez-Haro M, Taggart MA (2011) Bioaccessibility of $\mathrm{Pb}$ from ammunition in game meat is affected by cooking treatment. PLoS ONE 6(1): e15892. doi:10.1371/journal.pone.0015892.

Mateo R, Green AJ, Lefranc H, Baos R, Figuerola J (2007) Lead poisoning in wild birds from southern Spain: A comparative study of wetland areas and species affected, and trends over time. Ecotoxicol Environ Saf 66:119-126.

Mateo R, Vallverdú-Coll N, López-Antia A, Taggart MA, Martínez-Haro M, Guitart R, OrtizSantaliestra ME (2014) Reducing $\mathrm{Pb}$ poisoning in birds and $\mathrm{Pb}$ exposure in game meat consumers: the dual benefit of effective Pb shot regulation. Environ Int 63:163-168.

Mcconnell, CA (1968) Experimental lead poisoning of bobwhite quail and mourning doves. Proc Ann Conf Southeastern Assoc Game Fish Comm 21:208-219.

Mirarchi RE, Baskett TS (1994) Mourning dove (Zenaida macroura). In: Poole A and Gill F (eds) The birds of North America, 117. The American Ornithologist's Union, Washington, D.C., USA.

Mur P (2009) L'hivernage de la Caille des blés Coturnix coturnix en France. Alauda 77:103-114.

Nadal J, Ponz C, Comas C, Margalida A (2019) Time, geography and weather provide insights into the ecological strategy of a migrant species. Sci Total Environ 649:1096-1104. doi: 10.1016/j.scitotenv.2018.08.345. 
Nam DH, Lee DP (2006) Monitoring for $\mathrm{Pb}$ and Cd pollution using feral pigeons in rural, urban, and industrial environments of Korea. Sci Total Environ 357:288-295.

Pain DJ, Cromie R, Green RE (2015) Poisoning of birds and other wildlife from ammunitionderived lead in the UK. In: Delahay RJ and Spray CJ (eds.) Proceedings of the Oxford Lead Symposium Lead Ammunition: understanding and minimising the risks to human and environmental health, 58-83.

Pain DJ, Cromie RL, Newth J, Brown MJ, Crutcher E, Hardman P, Hurst L, Mateo R, Meharg AA, Moran AC, Raab A, Taggart MA, Green RE (2010) Potential Hazard to Human Health from Exposure to Fragments of Lead Bullets and Shot in the Tissues of Game Animals. PLoS ONE 5(4): e10315. doi:10.1371/journal.pone.0010315.

Pain DJ, Fisher IJ, Thomas VG (2009) A global update of lead poisoning in terrestrial birds from ammunition sources. In: Watson RT, Fuller M, Pokras M and Hunt WG (eds) Ingestion of Lead from Spent Ammunition: Implications for Wildlife and Humans. The Peregrine Fund, Boise, Idaho, USA, pp. 99-118.

Pain DJ, Mateo R, Green RE (2019) Effects of lead from ammunition on birds and other wildlife: A review and update. Ambio. https://doi.org/10.1007/s13280-019-01159-0.

Pattee OH, Carpenter JW, Fritts SH, Rattner BA, Wiemeyer SN, Royle JA, Smith MR (2006) Lead poisoning in captive Andean condors (Vultur gryphus). J Wildl Dis 42(4):772-779.

Pattee, OH, Pain DJ (2003) Lead in the environment. In: Hoffman DJ, Rattner BA, Burton GA Jr, and Cairns J Jr (eds) Handbook of ecotoxicology, Second ed., pp. 373-408. Boca Raton, Florida, USA: CRC Press.

Patrick L (2006) Lead toxicity, a review of the literature. Part 1: Exposure, evaluation, and treatment. Altern Med Rev 11(1):2-22. 
Peña-Fernández A, Lobo-Bedmar MC, González-Muñoz MJ (2015) Annual and seasonal variability of metals and metalloids in urban and industrial soils in Alcalá de Henares (Spain). Environ Res 136:40-46.

Pokras MA, Kneeland MR (2009) Understanding lead uptake and effects across species lines: a conservation medicine based approach. In: Watson RT, Fuller M, Pokras M and Hunt WG (eds) Ingestion of Lead from Spent Ammunition: Implications for Wildlife and Humans. The Peregrine Fund, Boise, Idaho, USA, pp. 7-22.

Potts GR (2005) Incidence of ingested lead gunshot in wild Grey Partridge (Perdix perdix) from the UK. Eur J WildI Res 51:31-34.

Schilderman PAEL, Hoogewerff JA, Schooten FJV, Maas LM, Moonen EJC, Os BJHV, Wijnen JHV, Kleinjans JCS (1997) Possible relevance of pigeons as an indicator species for monitoring air pollution. Environ Health Perspect 3(105):322-330.

Schulz JH, Millspaugh JJ, Washburn BE, Wester GR, Lanigan III, JT, Franson JC (2002) Spentshot availability and ingestion on areas managed for mourning doves. Wild Soc Bull 30:112-120.

Soler-Rodríguez F, Oropesa-Jiménez AL, García-Cambero JP, Pérez-López M (2004) Lead exposition by gunshot ingestion in Red-legged Partridge (Alectoris rufa). Vet Hum Toxicol 46:133-134.

Shotyk W, Le Roux G (2005) Biogeochemistry and cycling of lead. Met lons Biol Syst 43:239275.

Steinnes E (2013) Lead. In: Alloway B (ed) Heavy metals in soils. Environmental pollution, vol 22. Springer, Dordrecht. 
Tokar EJ, Boyd WA, Freedman JH, Waalkes MP (2013) Toxic effects of metals. In: Klaassen CD (ed) Casarett and Doull's toxicology: the basic science of poisons. McGraw-Hill, New York, pp. $981-1030$.

Tranel MA, Kimmel RO (2009) Impacts of lead ammunition on wildlife, the environment, and human health-A literature review and implications for Minnesota. In: Watson RT, Fuller M, Pokras $M$ and Hunt WG (eds) Ingestion of Lead from Spent Ammunition: Implications for Wildlife and Humans. The Peregrine Fund, Boise, Idaho, USA, 318-337.

US EPA (2003) United States Environmental Protection Agency. National air quality and emissions trends report-2003 special studies edition. EPA/454/R-03/005. Research Triangle Park, North Carolina, pp. 277.

US EPA (2014) United States Environmental Protection Agency, List of Priority Pollutants. URL https://www.epa.gov/sites/production/files/2015-09/documents/priority-pollutant-listepa.pdf.

Walter H, Reese KP (2003) Fall diet of Chukars (Alectoris chukar) in eastern Oregon and discovery of ingested lead pellets. West N Am Nat 63(3):402-405.

Watson M (2004) The effects of raptors on grey partridge populations. DPhil Thesis, University of Oxford.

Williams RJ, Holladay SD, Williams SM, Gogal RM Jr (2017) Environmental Lead and Wild Birds: A Review. Rev Environ Contam Toxicol 245:157-180.

Yamamoto K, Hayashi M, Yoshimura M, Hayashi H, Hiratsuka A, Isii Y. The Prevalence and Retention of Lead Pellets in Japanese Quail. Arch. Environ. Contam. Toxicol. 24, 478--482 (1993). 
Zhang W, Yang J, Wu X, Hu Y, Yu W, Wang J, Dong J, Li M, Liang S, Hu J, Kumar RV (2016) A critical review on secondary lead recycling technology and its prospect. Renew. Sustain. Energy Rev. 61, 108-122. 
Figure 1. Location of sampling areas from Spain.

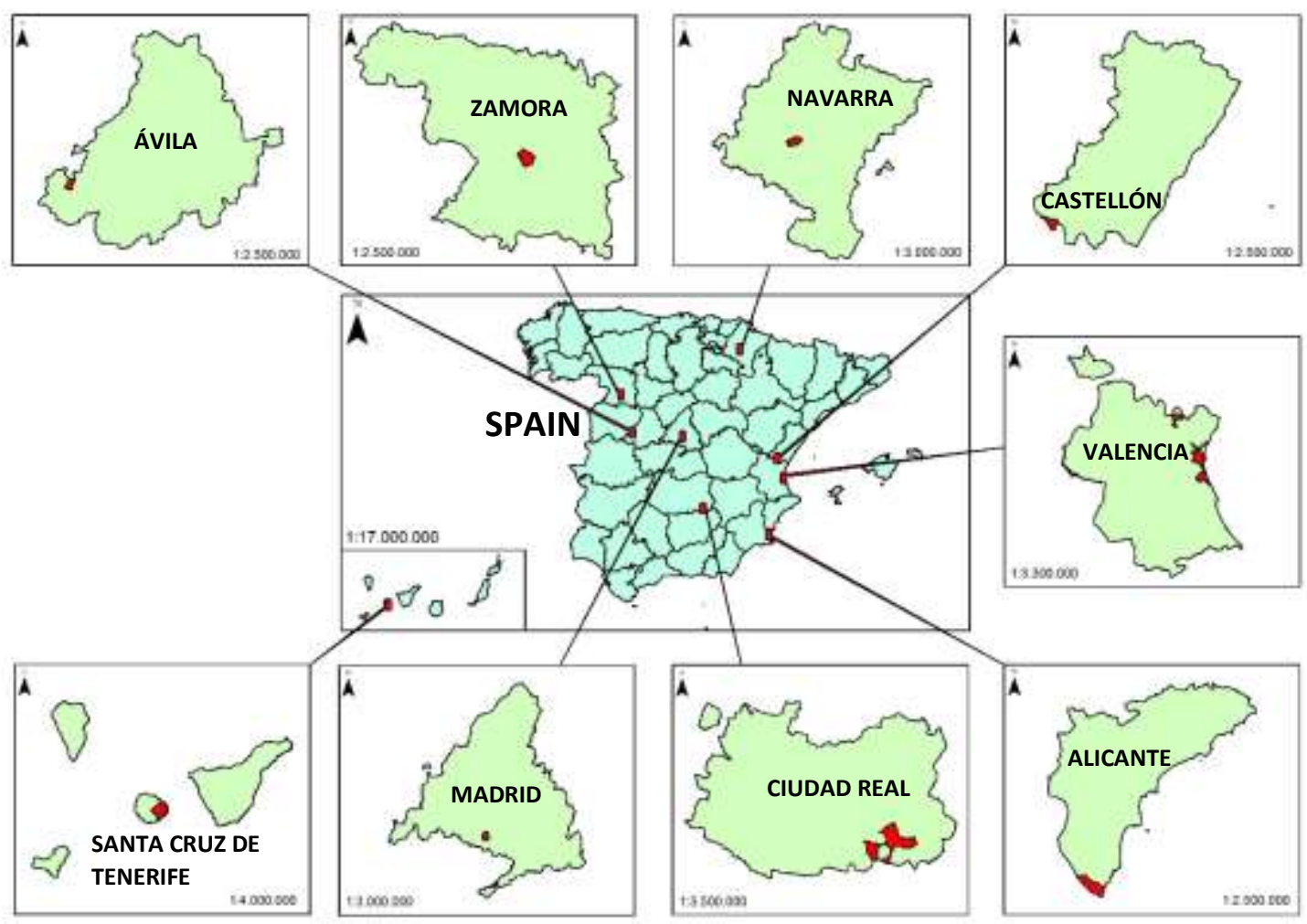


Table 1. Characteristics of the studied groups of birds, sampling areas and causes of death.

\begin{tabular}{|c|c|c|c|c|c|c|c|c|c|c|}
\hline Region & Species & Area & $n$ & Nature & Behaviour & Environment & $\begin{array}{c}\text { Sampling } \\
\text { method }\end{array}$ & Cause of death & $\begin{array}{c}\text { Hunting } \\
\text { intensity }\end{array}$ & Other \\
\hline \multirow{6}{*}{$\begin{array}{c}\text { Comunidad } \\
\text { Valenciana } \\
(n=191)\end{array}$} & Alectoris rufa & Valencia & 30 & Wild & Sedentary & Urban & $\begin{array}{l}\text { Urban control } \\
\text { program }\end{array}$ & $\begin{array}{l}\text { Bird of prey (24) } \\
\text { Compressed-air } \\
\text { guns (6) }\end{array}$ & Zero & Airport \\
\hline & Alectoris rufa & Alicante & 36 & Wild & Sedentary & Rural & Hunting & Firearms & Very high & $\begin{array}{c}\text { Claim } \\
\text { hunting }\end{array}$ \\
\hline & Columba livia & Valencia & 30 & Wild & Sedentary & Urban & \begin{tabular}{|c} 
Urban control \\
program
\end{tabular} & Lethal gas* & Zero & Seaport \\
\hline & $\begin{array}{l}\text { Columba } \\
\text { palumbus }\end{array}$ & Alicante & 30 & Wild & Sedentary & Rural & Hunting & Firearms & Very high & $\begin{array}{c}\text { Half-closed } \\
\text { season }\end{array}$ \\
\hline & $\begin{array}{l}\text { Columba } \\
\text { palumbus }\end{array}$ & Castellón & 2 & Wild & Sedentary & Rural & Hunting & Firearms & Low & $\begin{array}{c}\text { Half-closed } \\
\text { season }\end{array}$ \\
\hline & $\begin{array}{l}\text { Columba } \\
\text { palumbus }\end{array}$ & Castellón & 2 & Wild & Migration & Rural & Hunting & Firearms & Low & $\begin{array}{c}\text { General } \\
\text { hunting } \\
\text { season }\end{array}$ \\
\hline $\begin{array}{l}\text { Madrid } \\
(n=40)\end{array}$ & $\begin{array}{l}\text { Columba } \\
\text { palumbus }\end{array}$ & Madrid & 30 & Wild & Sedentary & Periurban & Hunting & Firearms & High & $\begin{array}{c}\text { Half-closed } \\
\text { season }\end{array}$ \\
\hline \multirow{3}{*}{$\begin{array}{l}\text { Castilla- } \\
\text { La Mancha } \\
\text { (n=97) }\end{array}$} & Alectoris rufa & $\begin{array}{c}\text { Ciudad Real } \\
\text { (HR 1) }\end{array}$ & 32 & Repopulation & Sedentary & Rural & Hunting & Firearms & High & $\begin{array}{l}\text { Start of } \\
\text { season }\end{array}$ \\
\hline & Alectoris rufa & $\begin{array}{c}\text { Ciudad Real } \\
(H R 2)\end{array}$ & 24 & Repopulation & Sedentary & Rural & Hunting & Firearms & High & $\begin{array}{c}\text { Middle of } \\
\text { season }\end{array}$ \\
\hline & Alectoris rufa & Ciudad Real & 17 & Repopulation & Sedentary & Rural & Hunting & Firearms & High & End of \\
\hline
\end{tabular}




\begin{tabular}{|c|c|c|c|c|c|c|c|c|c|c|}
\hline & & (HR 3) & & & & & & & & season \\
\hline & Alectoris rufa & $\begin{array}{c}\text { Ciudad Real } \\
(H R \text { 1) }\end{array}$ & 24 & Repopulation & Sedentary & Rural & Hunting & Firearms & High & $\begin{array}{l}\text { End of } \\
\text { season }\end{array}$ \\
\hline \multirow{7}{*}{$\begin{array}{l}\text { Castilla-León } \\
\qquad(n=162)\end{array}$} & Alectoris rufa & Zamora & 30 & Wild & Sedentary & Rural & Hunting & Firearms & Low & $\begin{array}{l}\text { General } \\
\text { hunting } \\
\text { season }\end{array}$ \\
\hline & Columba livia & Zamora & 28 & Wild & Sedentary & Rural & Hunting & Firearms & Low & $\begin{array}{l}\text { General } \\
\text { hunting } \\
\text { season }\end{array}$ \\
\hline & $\begin{array}{l}\text { Columba } \\
\text { palumbus }\end{array}$ & Zamora & 30 & Wild & Sedentary & Rural & Hunting & Firearms & Low & $\begin{array}{c}\text { Half-closed } \\
\text { season }\end{array}$ \\
\hline & $\begin{array}{l}\text { Columba } \\
\text { palumbus }\end{array}$ & Zamora & 12 & Wild & Migration & Rural & Hunting & Firearms & Low & $\begin{array}{l}\text { General } \\
\text { hunting } \\
\text { season }\end{array}$ \\
\hline & $\begin{array}{l}\text { Columba } \\
\text { palumbus }\end{array}$ & Ávila & 1 & Wild & Migration & Rural & Hunting & Firearms & Low & $\begin{array}{l}\text { General } \\
\text { hunting } \\
\text { season }\end{array}$ \\
\hline & $\begin{array}{c}\text { Columba } \\
\text { oenas }\end{array}$ & Zamora & 30 & Wild & Migration & Rural & Hunting & Firearms & Low & $\begin{array}{l}\text { General } \\
\text { hunting } \\
\text { season }\end{array}$ \\
\hline & $\begin{array}{l}\text { Coturnix } \\
\text { coturnix }\end{array}$ & Zamora & 31 & Wild & $\begin{array}{c}\text { Summer } \\
\text { migration }\end{array}$ & Rural & Hunting & Firearms & Low & $\begin{array}{c}\text { Half-closed } \\
\text { season }\end{array}$ \\
\hline \multirow{2}{*}{$\begin{array}{c}\text { Islas Canarias } \\
(n=14)\end{array}$} & $\begin{array}{l}\text { Alectoris } \\
\text { barbara }\end{array}$ & $\begin{array}{c}\text { Santa Cruz de } \\
\text { Tenerife }\end{array}$ & 13 & Wild & Sedentary & Rural & Hunting & Firearms & Very low & $\begin{array}{l}\text { General } \\
\text { hunting } \\
\text { season }\end{array}$ \\
\hline & Columba livia & $\begin{array}{c}\text { Santa Cruz de } \\
\text { Tenerife }\end{array}$ & 1 & Wild & Sedentary & Rural & Hunting & Firearms & Very low & $\begin{array}{l}\text { General } \\
\text { hunting } \\
\text { season }\end{array}$ \\
\hline $\begin{array}{c}\text { Navarra } \\
(n=26)\end{array}$ & Alectoris rufa & Navarra & 26 & Livestock & Sedentary & Rural & $\begin{array}{c}\text { Veterinary } \\
\text { practice }\end{array}$ & $\begin{array}{c}\text { Lethal } \\
\text { injection** }\end{array}$ & Zero & Farm \\
\hline
\end{tabular}

* authorisation code BIO/FC/15661/ 2103 2016; ** clinical veterinary practices, non-experimental; HR = hunting reserve 
Table 2. Concentrations of $\mathrm{Pb}\left(\mu \mathrm{g} \mathrm{g} \mathrm{g}^{-1}\right.$, wet weight) in game-bird livers and specimens with $\mathrm{Pb}$ shot, possibly due to ingestion.

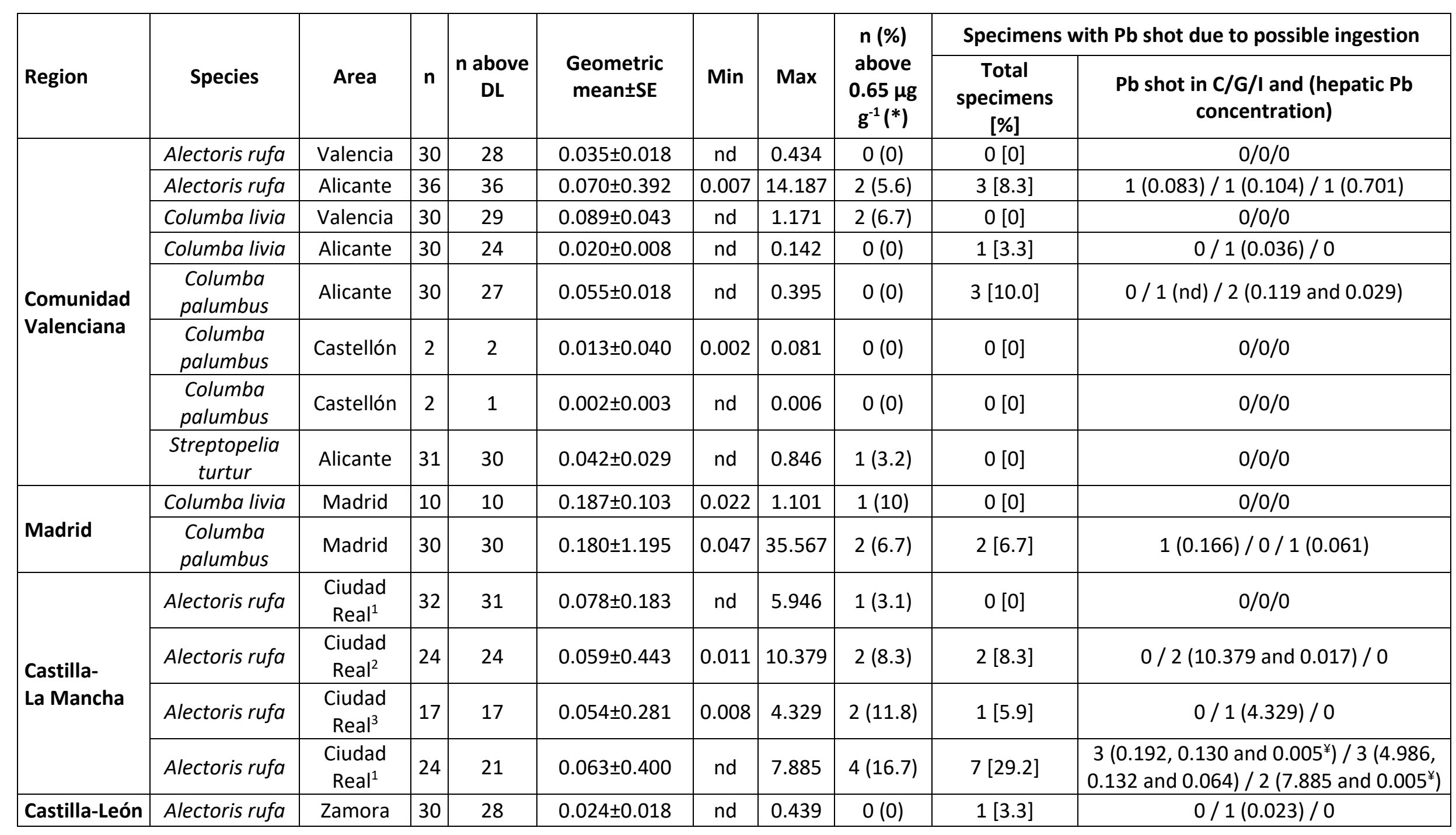




\begin{tabular}{|l|c|c|c|c|c|c|c|c|c|c|}
\hline \multirow{5}{*}{} & Columba livia & Zamora & 28 & 24 & $0.022 \pm 0.010$ & $\mathrm{nd}$ & 0.226 & $0(0)$ & $1[3.6]$ & $0 / 1\left(0.135^{\S}\right) / 1\left(0.135^{\S}\right)$ \\
\cline { 2 - 9 } & $\begin{array}{c}\text { Columba } \\
\text { palumbus }\end{array}$ & Zamora & 30 & 30 & $0.111 \pm 1.038$ & 0.034 & 31.253 & $1(3.3)$ & $5[16.7]$ & $\begin{array}{c}1(31.253) / 1(0.082) / 3(0.299,0.176 \\
\text { and 0.049) }\end{array}$ \\
\cline { 2 - 10 } & $\begin{array}{c}\text { Columba } \\
\text { palumbus }\end{array}$ & Zamora & 12 & 9 & $0.018 \pm 0.230$ & $\mathrm{nd}$ & 2.788 & $1(8.3)$ & $0[0]$ & $0 / 0 / 0$ \\
$\begin{array}{c}\text { Columba } \\
\text { palumbus }\end{array}$ & Ávila & 1 & 0 & $\mathrm{nd}$ & - & - & $0(0)$ & $0[0]$ & $0 / 0 / 0$ \\
\cline { 2 - 10 } & $\begin{array}{c}\text { Columba } \\
\text { oenas }\end{array}$ & Zamora & 30 & 28 & $0.033 \pm 0.006$ & $\mathrm{nd}$ & 0.151 & $0(0)$ & $1[3.3]$ & $0 / 1(0.151) / 0$ \\
\cline { 2 - 9 } & $\begin{array}{c}\text { Coturnix } \\
\text { coturnix }\end{array}$ & Zamora & 31 & 31 & $0.121 \pm 0.213$ & 0.028 & 6.270 & $2(6.5)$ & $0[0]$ & $0 / 0 / 0$ \\
\hline \multirow{5}{*}{ Canarias } & $\begin{array}{c}\text { Alectoris } \\
\text { barbara }\end{array}$ & $\begin{array}{c}\text { S. C. } \\
\text { Tenerife }\end{array}$ & 13 & 13 & $0.091 \pm 0.879$ & 0.002 & 8.766 & $3(23.1)$ & $1[7.7]$ & $0 / 1(0.255) / 0$ \\
\hline Navarra & Columba livia & $\begin{array}{c}\text { S. C. } \\
\text { Tenerife }\end{array}$ & 1 & 1 & $0.165 \pm$ & 0.165 & 0.165 & $0(0)$ & $0[0]$ & $0 / 0 / 0$ \\
\hline
\end{tabular}

$\left({ }^{*}\right)$ threshold of abnormal exposure; C=crop, G=gizzard, I=intestine; nd=no detected; ${ }^{1}$ hunting reserve $1 ;{ }^{2}$ hunting reserve $2 ;{ }^{3}$ hunting reserve 3 ; ${ }^{*}$ same specimen (one specimen had one $\mathrm{Pb}$ pellet in crop and another one in its intestine); ${ }^{\S}$ same specimen (the same specimen had one $\mathrm{Pb}$ pellet in its gizzard and another one in its intestine) 
Table 3. Hepatic $\mathrm{Pb}$ concentrations ( $\mu \mathrm{g} \mathrm{g}^{-1}$ wet weight) in each species by location. For each species, the same small letter indicates statistically significant differences between locations.

\begin{tabular}{|l|l|c|c|}
\hline Species & Area & $\mathbf{n}$ & Geometric mean \pm SE \\
\hline \multirow{4}{*}{ Alectoris rufa } & Alicante & 36 & $0.070 \pm 0.392^{\mathrm{a}, \mathrm{b}}$ \\
\cline { 2 - 4 } & Ciudad Real & 97 & $0.065 \pm 0.166^{\mathrm{c}}$ \\
\cline { 2 - 4 } & Navarra & 26 & $0.060 \pm 0.011^{\mathrm{d}}$ \\
\cline { 2 - 4 } & Valencia & 30 & $0.035 \pm 0.018^{\mathrm{a}}$ \\
\cline { 2 - 4 } & Zamora & 30 & $0.024 \pm 0.018^{\mathrm{b}, \mathrm{c}, \mathrm{d}}$ \\
\hline \multirow{5}{*}{ Columba palumbus } & Madrid & 30 & $0.180 \pm 1.195^{\mathrm{e}, \mathrm{f}}$ \\
\cline { 2 - 4 } & Zamora & 42 & $0.065 \pm 0.743^{\mathrm{e}}$ \\
\cline { 2 - 4 } & Alicante & 30 & $0.055 \pm 0.018^{\mathrm{f}}$ \\
\cline { 2 - 4 } & Castellón* & 4 & $0.005 \pm 0.020$ \\
\cline { 2 - 4 } & Avila* & 1 & $\mathrm{nd}$ \\
\hline & Madrid & 10 & $0.187 \pm 0.103^{\mathrm{g}, \mathrm{h}}$ \\
\cline { 2 - 4 } & La Gomera* & 1 & 0.165 \\
\cline { 2 - 4 } & Valencia & 30 & $0.089 \pm 0.043^{\mathrm{i}, \mathrm{j}}$ \\
\cline { 2 - 4 } & Zamora & 28 & $0.022 \pm 0.010^{\mathrm{g}, \mathrm{i}}$ \\
\cline { 2 - 4 } & Alicante & 30 & $0.020 \pm 0.008^{\mathrm{h}, \mathrm{j}}$ \\
\hline
\end{tabular}

*excluded from the statistical analyses; nd=not detected 
Table 4. Hepatic $\mathrm{Pb}$ concentrations ( $\mu \mathrm{g} \mathrm{g}^{-1}$ wet weight) in each location by species. For each location, the same small letter indicates statistically significant differences between species.

\begin{tabular}{|l|l|c|c|}
\hline Area & Species & $\mathbf{n}$ & Geometric mean \pm SE \\
\hline \multirow{5}{*}{ Zamora } & Coturnix coturnix & 31 & $0.121 \pm 0.213^{\mathrm{a}, \mathrm{b}, \mathrm{c}}$ \\
\cline { 2 - 4 } & Columba palumbus & 42 & $0.065 \pm 0.743^{\mathrm{d}}$ \\
\cline { 2 - 4 } & Columba oenas & 30 & $0.033 \pm 0.006^{\mathrm{a}}$ \\
\cline { 2 - 4 } & Alectoris rufa & 30 & $0.024 \pm 0.018^{\mathrm{b}}$ \\
\cline { 2 - 4 } & Columba livia & 28 & $0.022 \pm 0.010^{\mathrm{c}, \mathrm{d}}$ \\
\hline \multirow{4}{*}{ Alicadrid } & Columba livia & 10 & $0.187 \pm 0.103$ \\
\cline { 2 - 4 } & Columba palumbus & 30 & $0.180 \pm 1.195$ \\
\hline \multirow{4}{*}{ Valencia } & Alectoris rufa & 36 & $0.070 \pm 0.392^{\mathrm{e}}$ \\
\cline { 2 - 4 } & Columba palumbus & 30 & $0.055 \pm 0.018^{\mathrm{f}}$ \\
\cline { 2 - 4 } & Streptopelia turtur & 31 & $0.042 \pm 0.029$ \\
\cline { 2 - 4 } & Columba livia & 30 & $0.020 \pm 0.008^{\mathrm{e}, \mathrm{f}}$ \\
\cline { 2 - 4 } & Columba livia & 30 & $0.089 \pm 0.043^{\mathrm{g}}$ \\
\hline
\end{tabular}


Table 5. Hepatic $\mathrm{Pb}$ concentrations ( $\mu \mathrm{g} \mathrm{g}^{-1}$, wet weight) in birds from areas with different hunting intensities, and possible Pb shot ingestion. The same small letter indicates statistically significant differences between intensity hunting areas. The same capital letter indicates statistically significant differences between the intensity hunting areas for the same species.

\begin{tabular}{|c|c|c|c|c|c|c|}
\hline Hunting intensity & $\mathbf{n}$ & Geometric mean \pm SE & Possible Pb shot ingestion & Species & Geometric mean $\pm S E$ & Possible $\mathrm{Pb}$ shot ingestion \\
\hline \multirow{2}{*}{ Very high } & \multirow{2}{*}{127} & \multirow{2}{*}{$0.044 \pm 0.111^{\mathrm{a}}$} & \multirow{2}{*}{7} & Columba palumbus, $\mathrm{n}=30$ & $0.055 \pm 0.018^{A}$ & 3 \\
\hline & & & & Streptopelia turtur, n=31 & $0.042 \pm 0.029$ & 0 \\
\hline \multirow{3}{*}{ High } & \multirow{3}{*}{137} & \multirow{3}{*}{$0.088 \pm 0.286^{a, b}$} & \multirow{3}{*}{12} & Columba palumbus, $\mathrm{n}=30$ & $0.180 \pm 1.195^{\mathrm{A}, \mathrm{B}}$ & 2 \\
\hline & & & & Columba livia, $\mathrm{n}=10$ & $0.187 \pm 0.103^{C, D}$ & 0 \\
\hline & & & & Alectoris rufa, $\mathrm{n}=97$ & $0.065 \pm 0.166^{\mathrm{E}}$ & 10 \\
\hline \multirow{4}{*}{ Low } & \multirow{4}{*}{166} & \multirow{4}{*}{$0.041 \pm 0.192^{b}$} & \multirow{4}{*}{8} & Columba palumbus, $\mathrm{n}=47$ & $0.047 \pm 0.665^{B}$ & 5 \\
\hline & & & & Columba livia, $\mathrm{n}=28$ & $0.022 \pm 0.010^{\mathrm{D}}$ & 1 \\
\hline & & & & Alectoris rufa, $\mathrm{n}=30$ & $0.024 \pm 0.018^{\mathrm{E}, \mathrm{F}}$ & 1 \\
\hline & & & & Coturnix coturnix, $\mathrm{n}=31$ & $0.121 \pm 0.213$ & 0 \\
\hline \multirow{2}{*}{ Very low } & \multirow{2}{*}{14} & \multirow{2}{*}{$0.095 \pm 0.819$} & \multirow{2}{*}{1} & Alectoris barbara, $\mathrm{n}=13$ & $0.091 \pm 0.879$ & 1 \\
\hline & & & & Columba livia, $\mathrm{n}=1$ & 0.165 & 0 \\
\hline \multirow{2}{*}{ Zero* } & \multirow{2}{*}{86} & \multirow{2}{*}{$0.057 \pm 0.017$} & \multirow{2}{*}{ - } & Columba livia, $\mathrm{n}=30$ & $0.089 \pm 0.043$ & - \\
\hline & & & & Alectoris rufa, $\mathrm{n}=56$ & $0.045 \pm 0.011$ & - \\
\hline
\end{tabular}

*excluded from the statistical analyses 
Table 6. $\mathrm{Pb}$ pellet ingestion in game birds from terrestrial environments.

\begin{tabular}{|c|c|c|c|c|}
\hline Species & $\mathbf{n}$ & Country & $\begin{array}{l}\text { Birds with } \mathrm{Pb} \\
\text { pellets } \\
\text { in gizzards (\%) }\end{array}$ & Reference \\
\hline \multirow{4}{*}{ Alectoris rufa } & 7 & Spain & 14.3 & $\begin{array}{l}\text { Soler-Rodríguez et al., } \\
2004\end{array}$ \\
\hline & 637 & $\begin{array}{c}\text { United } \\
\text { Kingdom }\end{array}$ & $0.16^{*}$ & Butler et al., 2005 \\
\hline & 144 & $\begin{array}{c}\text { United } \\
\text { Kingdom }\end{array}$ & $1.4^{* *}$ & Butler et al., 2005 \\
\hline & 76 & Spain & 7.8 & Ferrandis et al., 2008 \\
\hline \multirow{3}{*}{ Perdix perdix } & 62 & Denmark & 1.6 & $\begin{array}{l}\text { Clausen and Wolstrup, } \\
1979\end{array}$ \\
\hline & 77 & $\begin{array}{c}\text { United } \\
\text { Kingdom }\end{array}$ & 0 & Watson, 2004 \\
\hline & 1318 & $\begin{array}{c}\text { United } \\
\text { Kingdom }\end{array}$ & 1.4 & Potts, 2005 \\
\hline \multirow{4}{*}{ Alectoris chukar } & 123 & USA & 5.7 & Walter and Reese, 2003 \\
\hline & 75 & USA & 10.7 & Larsen et al., 2007 \\
\hline & 76 & Canada & 8 & Kreager et al., 2008 \\
\hline & 461 & USA & 9.3 & Bingham et al., 2015 \\
\hline $\begin{array}{l}\text { Columba } \\
\text { palumbus }\end{array}$ & 142 & Denmark & 0.7 & $\begin{array}{l}\text { Clausen and Wolstrup, } \\
1979\end{array}$ \\
\hline Columba livia & 13 & USA & 23.1 & DeMent et al., 1987 \\
\hline \multirow{3}{*}{$\begin{array}{l}\text { Phasianus } \\
\text { colchicus }\end{array}$} & 947 & Hungary & 4.75 & Ákoshegyi, 1997 \\
\hline & 437 & $\begin{array}{c}\text { United } \\
\text { Kingdom }\end{array}$ & 3 & Butler, 2005 \\
\hline & 47 & Canada & 34 & Kreager et al., 2008 \\
\hline
\end{tabular}

*historical; ** current (2005) 